\section{Diphenhydramine prevents the haemo- dynamic changes of cimetidine in ICU patients}

K. Omote MD PhD, A. Namiki MD PhD,

H. Iwasaki MD PhD, Y. Ujike MD PhD
Cimetidine, a histamine $2\left(\mathrm{H}_{2}\right)$ antagonist, produces a decrease in arterial pressure due to vasodilatation, especially in critically ill patients. This may be because cimetidine acts as a histamine agonist. We, therefore, investigated the effects of the histamine $I\left(H_{l}\right)$ receptor antagonist, diphenhydramine, on the haemodynamic changes observed after cimetidine in ICU patients. Each patient was studied on two separate days. In a random fashion, they received cimetidine $200 \mathrm{mg}$ iv on one day, and on the other, a pretreatment of diphenhydramine $40 \mathrm{mg}$ iv with cimetidine $200 \mathrm{mg}$ iv. In the non-pretreatment group, mean arterial pressure (MAP) decreased from $107.4 \pm 8.4 \mathrm{mmHg}$ to $86.7 \pm$ $11.4 \mathrm{mmHg}(P<0.01)$ two minutes after cimetidine. Also, systemic vascular resisfance (SVR) decreased during the eightminute observation period $(P<0.01)$. In contrast, in the pretreatment group, little haemodynamic change was seen. We conclude that an $H_{1}$ antagonist may be usefut in preventing hypotension caused by iv cimesidine, since the vasodilating activity of cimetidine is mediated, in part, through the $H_{l}$ receptor.

La cimétidine, un bloqueur des récepteurs histaminiques de type $2\left(\mathrm{H}_{2}\right)$, induit une vasodilatation entrainant de l'hypotension surtout chez les grands malades. Une stimulation des récepteurs $H_{1}$ pourrait en être la cause. Nous avons donc étudié l'influence de la diphenhydramine, un bloqueur $H_{l}$, sur les effets hémodynamiques de la cimétidine aux soins intensifs. Chaque patient participait à deux jours de séance expérimentale soit une injection de $200 \mathrm{mg}$ de cimésidine iv précédée en une occasion

\section{Key words}

BLOOD PRESSURE: hypotension;

HISTAMINE: cimetidine, diphenhydramine.

From The Department of Anesthesiology, Sapporo Medical College and Hospital, Sapporo, Japan.

Address correspondence to: Dr. K. Omote, Department of Anesthesiology, Sapporo Medical College and Hospital, South-1, West-16, Chuoku, Sapporo city, Hokkaido, 060 Japan.

Accepted for publication 10th October, 1990. randomisée de $40 \mathrm{mg}$ de diphenhydramine iv. Deux minutes après l'injection de cimétidine seule, la tension artérielle moyenne passait de 107,4 $\pm 8,4$ a $86,7 \pm 11,4 \mathrm{mmHg}(P<$ $0.01)$ el la résistance vasculaire systémique diminuait pendant au moins huil minutes $(P<0,01)$. Lorsque que la cimétidine était précédée de diphenhydramine, les variables hémodynamiques restaient stables. Les bloqueurs des récepteurs histaminiques $H_{I}$ peuvent donc prévenir l'hypotension associée à la cimétidine puisque que cette dernière stimule les récepteurs $H_{I}$ entrainant une vasodilatation.

Histamine $\mathrm{H}_{2}$ receptor antagonists are frequently used for the prevention and treatment of gastrointestinal bleeding in critically ill patients. Cimetidine iv transiently decreases mean arterial pressure (MAP) by decreasing systemic vascular resistance (SVR) in ICU patients. ${ }^{1-3}$ The mechanism of this effect is not well defined. The $H_{1}$ agonists produce peripheral vasodilatation in man. ${ }^{4}$ Cimetidine, like histamine, possesses an imidazole ring in the structure. The newer $\mathrm{H}_{2}$ antagonists, ranitidine and famotidine, do not possess imidazole rings (Figure), and have few adverse cardiovascular effects. ${ }^{2,5-7}$ This suggests that cimetidine might act as an agonist at $\mathrm{H}_{1}$ receptors. Therefore, the effects of $H_{1}$ receptor blockade on the haemodynamic response to iv cimetidine were studied.

\section{Methods}

This study was approved by the ethics committee of our institute and informed consent was obtained from the patient's next of kin. Five male and two female ICU patients, ranging in age from 35 to $83(58.8 \pm 13.2 \mathrm{yr})$ were studied. The diagnoses of the patients were acute respiratory insufficiency, pulmonary infarction and COPD. All patients were haemodynamically stable and none was treated with vasopressors or inotropic agents during the study. The lungs of all patients were mechanically ventilated with continuous positive-pressure ventilation. None of the patients had catheters inserted solely for the purpose of this study, but each had a radial arterial 


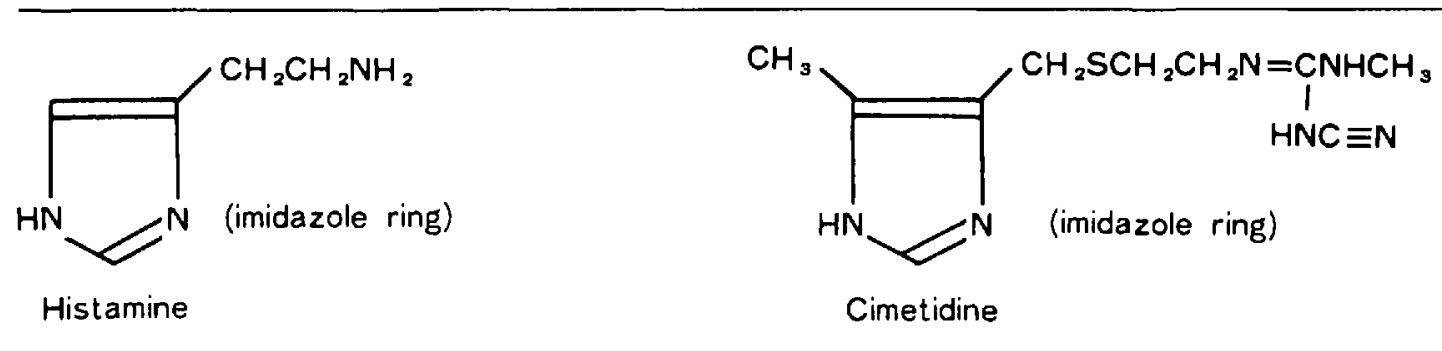

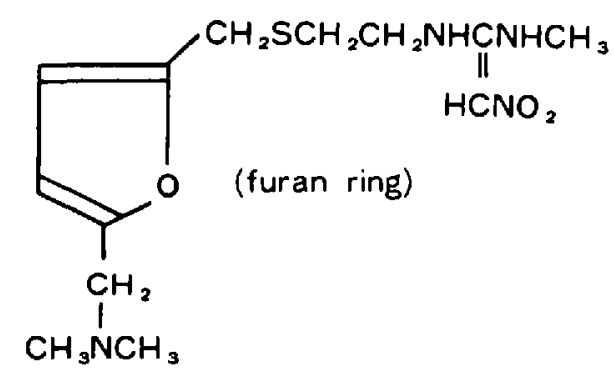

Ranitidine

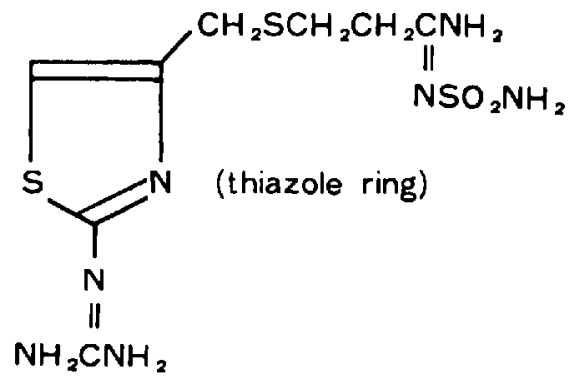

Famotidine

FIGURE Chemical structures of histamine, cimetidine, ranitidine and famolidine. Note that both histamine and cimetidine possess imidazole ring in their structures. Ranitidine and famolidine possess a different ring.

cannula and a balloon-tipped, flow-directed thermodilution pulmonary artery catheter.

Each patient was studied on two separate days. In a random fashion, they received on one day cimetidine iv and on the other a pretreatment of diphenhydriamine iv followed by cimetidine iv. Baseline haemodynamic data, including heart rate (HR), mean arterial pressure (MAP), mean pulmonary artery pressure (MPAP), pulmonary capillary wedge pressure (PCWP), central venous pressure (CVP) and cardiac output (CO), were obtained. All pressures were measured at end-expiration by calibrated transducers. Cardiac index $(\mathrm{CI})$, systemic vascular resistance (SVR), and pulmonary vascular resistance (PVR) were calculated by standard formulae.

Diphenhydramine $40 \mathrm{mg}$ or normal saline was given iv five minutes before the administration of cimetidine. Cimetidine $200 \mathrm{mg}$ in $20 \mathrm{ml}$ saline was administered iv over two minutes. The haemodynamic variables were measured at preinjection of cimetidine and at two, four and eight minutes after the injection was completed. During the study, the ventilatory settings and fluid management were unchanged.

For statistical analysis, ANOVA followed by Student's $t$ test was used for comparison within and between the groups. $P$ values of $<0.05$ were considered significant.

\section{Results}

The results of the haemodynamic effects of cimetidine in the patients with and without diphenhydramine pretreatment are summarized in Tables I and II. Baseline

TABLE I Haemodynamic effects of cimetidine

\begin{tabular}{lcccc}
\hline & Control & $2 \min$ & $4 \min$ & $8 \min$ \\
\hline HR (beat $\left.\cdot \mathrm{min}^{-1}\right)$ & $110.7 \pm 13.4$ & $111.1 \pm 17.1$ & $106.5 \pm 15.3$ & $105.4 \pm 14.8$ \\
MAP $(\mathrm{mmHg})$ & $107.4 \pm 8.4$ & $86.7 \pm 11.4 \dagger$ & $97.6 \pm 13.2 *$ & $100.2 \pm 13.3$ \\
MPAP $(\mathrm{mmHg})$ & $30.9 \pm 10.6$ & $30.5 \pm 12.2$ & $30.9 \pm 11.6$ & $31.3 \pm 10.4$ \\
PCWP $(\mathrm{mmHg})$ & $14.0 \pm 6.9$ & $13.8 \pm 6.5$ & $14.2 \pm 6.7$ & $15.1 \pm 6.8$ \\
CVP $(\mathrm{mmHg})$ & $6.0 \pm 1.5$ & $6.0 \pm 1.4$ & $6.3 \pm 1.1$ & $6.5 \pm 1.2$ \\
CI $\left(\mathrm{L} \cdot \mathrm{min}^{-1} \cdot \mathrm{m}^{-2}\right)$ & $3.95 \pm 0.34$ & $4.32 \pm 0.48$ & $4.23 \pm 0.51$ & $4.27 \pm 0.62$ \\
SVR (dynes $\left.\cdot \mathrm{sec} \cdot \mathrm{cm}^{-5}\right)$ & $1281.5 \pm 181.7$ & $956.7 \pm 195.7 \dagger$ & $1102.3 \pm 214.2 \dagger$ & $1124.1 \pm 207.4 \dagger$ \\
PVR (dynes $\left.\cdot \mathrm{sec} \cdot \mathrm{cm}^{-5}\right)$ & $216.0 \pm 148.4$ & $197.9 \pm 158.1$ & $201.0 \pm 162.9$ & $198.1 \pm 154.0$ \\
\hline
\end{tabular}

Means $\pm S D$

* $P<0.05$ compared with control value.

$\dagger P<0.01$ compared with control value. 
TABLE II Haemodynamic effects of cimetidine after diphenhydamine pretreatment

\begin{tabular}{lcccc}
\hline & Conirol & $2 \min$ & $4 \min$ & $8 \min$ \\
\hline HR (beat $\left.\cdot \mathrm{min}^{-1}\right)$ & $99.0 \pm 17.5$ & $101.2 \pm 18.1$ & $98.4 \pm 17.2$ & $98.0 \pm 17.0$ \\
MAP $(\mathrm{mmHg})$ & $110.2 \pm 6.0$ & $103.4 \pm 7.7$ & $105.5 \pm 7.7$ & $107.5 \pm 9.5$ \\
MPAP $(\mathrm{mmHg})$ & $30.6 \pm 7.5$ & $29.9 \pm 7.7$ & $30.1 \pm 8.6$ & $29.7 \pm 7.9$ \\
PCWP $(\mathrm{mmHg})$ & $16.1 \pm 8.8$ & $16.5 \pm 8.1$ & $16.5 \pm 8.2$ & $16.5 \pm 8.6$ \\
CVP $(\mathrm{mmHg})$ & $7.3 \pm 3.3$ & $7.3 \pm 3.1$ & $7.1 \pm 3.4$ & $7.1 \pm 3.4$ \\
Cl $\left(\mathrm{L} \cdot \mathrm{min}^{-1} \cdot \mathrm{m}^{-2}\right)$ & $4.31 \pm 0.94$ & $4.33 \pm 0.74$ & $4.33 \pm 0.84$ & $4.38 \pm 0.85$ \\
SVR (dynes $\left.\cdot \mathrm{sec} \cdot \mathrm{cm}^{-5}\right)$ & $1268.3 \pm 322.4$ & $1152.2 \pm 233.6$ & $1184.1 \pm 246.0$ & $1198.2 \pm 269.0$ \\
PVR (dynes $\left.\cdot \mathrm{sec} \cdot \mathrm{cm}^{-5}\right)$ & $185.1 \pm 122.5$ & $165.2 \pm 116.3$ & $169.8 \pm 118.8$ & $162.2 \pm 124.0$ \\
\hline
\end{tabular}

Means \pm SD.

haemodynamic values before cimetidine administration were comparable between the two groups.

In the non-pretreatment group, MAP decreased significantly two minutes $(P<0.01)$ and four minutes $(P<$ 0.05 ) after cimetidine, followed by recovery to the baseline value at eight minutes. SVR also decreased significantly for the duration of the study $(P<0.01)$ (Table I).

In contrast to the non-pretreatment group, the group pretreated with diphenhydramine demonstrated only a slight or non-significant change in MAP and SVR (Table II).

The other haemodynamic variables did not demonstrate any significant changes in either group.

\section{Discussion}

The present study demonstrated that diphenhydramine, an $\mathrm{H}_{1}$ antagonist, prevented cimetidine-induced peripheral vasodilatation followed by a reduction in MAP in critically ill patients. This suggests that cimetidine acts as an $\mathrm{H}_{1}$ agonist as well as an $\mathrm{H}_{2}$ antagonist.

Other newer $\mathrm{H}_{2}$ antagonists, ranitidine and famotidine do not have the same vasodilating properties as cimetidine in critically ill patients. ${ }^{2,5-7}$ This difference may be related to their different ring structures (Figure). Histamine and cimetidine possess an imidazole ring, while ranitidine and famotidine possess another ring (furan and thiazole ring, respectively) in their structures. It seems that the imidazole ring activates peripheral vasodilatation mediated through the $\mathrm{H}_{1}$ receptor and this may explain the lack of haemodynamic effect after ranitidine and famotidine, but not cimetidine.

Kato et $a l^{8}$ reported that the increase of peripheral blood flow by cimetidine was not influenced by diphenhydramine in anaesthetized dogs. However, there are species differences in the cardiovascular responses of histamine. ${ }^{9}$

In conclusion, it was demonstrated that diphenhydramine prevented a reduction in MAP due to vasodilatation caused by cimetidine. We suggest that the vasodilating activity of cimetidine is mediated through the $\mathrm{H}_{1}$ receptor and that $H_{1}$ antagonism may be useful in preventing the haemodynamic changes caused by cimetidine, especially in critically ill patients.

\section{References}

1 Iberti TJ, Paluch TA, Helmer L, Murgolo VA, Benjamin $E$. The hemodynamic effects of intravenous cimetidine in intensive care unit patients: a double-blinded, prospective study. Anesthesiology 1986; 64: 87-9.

2 Coursin DB, Farin-Rusk C, Springman SR, Goelzer $S L$. The hemodynamic effects of cimetidine versus ranitidine in intensive care unit patients: a double-blind, prospective, cross-over study. Anesthesiology 1988; 69: 975-8.

3 Smith $C L$, Bardgell DM. Hunter JM. Haemodynamic effects of the iv administration of cimetidine or ranitidine in the critically ill patient: a double-blind prospective study. Br J Anaesth 1987; 59: 1397-402.

4 Boyce MJ. Pharmacological characterization of cardiovascular histamine receptors in man in vivo. Klin Wochenschr 1982; 60: 978-82.

5 Goelzer SL, Farin-Rush C, Coursin DB. Ranitidine produces minimal hemodynamic depression in stable intensive care unit patients: a double-blind, prospective study. Crit Care Med 1988; 16: 8-10.

6 Omote K, Namiki A, Sumita S, Takahashi T, Ujike $Y$, Hagiwara $T$. Comparative studies on hemadynamic effects of intravenous cimetidine, ranitidine and famotidine in intensive care unit patients. Masui 1987; 36: 940-7.

7 Matsukawa S, Hoshi K, Kaise A, Sasaki I, Hashimoto Y, Amaha $K$. The cardiovascular effect of famotidine in intensive care patients. Joumal of Intensive Care Medicine 1986; 10: 763-7.

8 Kato H, Kurihara J, Kasuya Y. Cardiovascular effects of cimetidine. Arch Int Pharmacodyn Ther 1981; 249: 247-56.

9 Dale $H H$. Some chemical factors in the control of the circulation. Lancet 1929; 1: 1233-7. 